\title{
ASSESSMENT OF POTENTIAL PHYTO- AND GENOTOXICITY INDUCED BY SOME IMIDACLOPRID- BASED INSECTICIDES ON A NON-TARGET CROP AND HIGHER PLANT ASSAY
}

\author{
Anila Dizdari*, Ueda Bala \\ *University "Luigj Gurakuqi”, Faculty of Natural Sciences, Department of Biology and Chemistry, \\ Shkodër, Albania : \\ *Correspondence author Anila Dizdari, e- mail: aniladizdari@yahoo.it; ueda.bala@outlook.com;
}

Received March 2019; Accepted April 2019; Published June 2019;

DOI: https://doi.org/10.31407/ijees9216

UOI license: http://u-o-i.org/1.01/ijees/51059074

\begin{abstract}
Environmental pollution issues due to increased use and often incorrect appliance of pesticides are harmful phenomena constantly encountered in developing countries as Albania. The current study assessed the toxicity induced by short-term exposure of seeds and bulbs of Allium серa $\mathrm{L}$. to commercial formulations of imidaclopridbased insecticides. The biological materials were exposed for $12,24,48$ and $72 \mathrm{~h}$ to three experimental doses $(1.5,3$ and $4.5 \mathrm{gr} / \mathrm{L}$ ) of KOHINOR 200 SL, PULSAR 200 SL MALLET 20 SL and MIDAS. Phytotoxicity was determined through the limitation of seed germination capacity, reduction of longitudinal root growth and mitotic index, while genotoxicity inducement by scoring frequencies of micronuclei and chromosome abnormalities in root meristem. All evaluated parameters obviously varied in insecticide formulation-, concentration- and time exposure-dependent manner. The results detected suppression of seed germination and significant root growth restriction after 48- and 72-hour treatments, particularly for PULSAR and MIDAS. Additionally, the strongest mito-depressive activity was revealed since at the medium concentrations, incurring sublethal effect to meristematic cells. Excluding the lowest concentrations, the other tested ones could generally induce presence of micronuclei and significant frequencies of chromosomal abnormalities after 24-72 h exposure duration, revealing the confident genotoxic effects and potential mutagenicity of imidacloprid-based insecticides under study. This simulating investigation highlighted the capability of a common crop in Albania and higher plant assay as onion in recognizing and predicting insecticides pollution likewise induction of environmental stress with potential toxic consequences on food chain consumers and human population health.
\end{abstract}

Key words: imidacloprid- based insecticides, phytotoxicity, genotoxicity, Allium cepa L. assay 